\title{
Musical Tradition and Cultural Vision in Langston Hughes's Poetry
}

\author{
Lekha Nath Dhakal \\ Assocauite Professor of English, Minbhavan Campus, \\ Tribhuvan University, Kathmandu, Nepal
}

\begin{abstract}
In American music, Langston Hughes is one of the literary figures that hold a place similar to the aforementioned luminaries. In the literary field, Hughes is respected as one of the most important figures of the twentieth century. With the rise of African American Studies as an academic field in the 1970s, his life, writing, and influence has received frequent attention. What has not been documented in more specific terms is his importance to America's musical culture in the twentieth century. Whether directly or indirectly, Langston Hughes has been a fixture in American musical culture, both popular and concert music, since the 1920s. In addition to his personal affinity for blues, jazz and other specifically African American musical forms such as gospel music, his vast contribution to American music specifically and American music culture in a broader sense can be separated into four general categories.
\end{abstract}

In the midst of the Harlem Renaissance, Langston Hughes sought to change the way the world looked at art and African-Americans. He not only spent his life climbing the racial mountain and living and affirming an African American self, but also affirming what Ralph Ellison called in Invisible Man the principle "dreamed into being out of the chaos and darkness of the feudal past" (574). "Freedom! / Brotherhood! / Democracy!" Hughes hallelujahed in "Freedom's Plow:" .. for everybody, for all America, for all the world. May its branches spread and its shelter grow until all people know its shade (Selected Poems299).

Hughes could throw one arm around spirituals and gospel music and the other around the blues simultaneously would seem remarkable, even blasphemous, in some circles, primarily Christian ones where the blues might be dubbed "the devil's music". But Hughes sat them rather comfortably side by side in his work and his ethos: "I like the barrel houses of Seventh Street, the shouting churches, and the songs," he wrote in The Big Sea (209); the following year he called spirituals and blues the "two great Negro gifts to American music" ("Songs Called the Blues," 143).

Hughes did not exalt spirituals and gospel to glorify and preach Christianity. "The Big Sea" from Selected Poems outlines his traumatic conversion experience that left him doubting the existence of a Jesus who had not come to help him (18-21). As for Hughes, it was not meaning of words so much as the wording of the means that carried him away. What Hughes said about the blues in "Songs Called the Blues" applies to gospel music as well: "You don't have to understand the words to know the meaning of the blues, or to feel their sadness or hope their hopes" (145). Paul Oliver's description of gospel music captures the essence of the spark of gospel music that ignited Hughes:

Gospel songs, the message of "good news" and are so called, according to some preachers, because they state the "gospel truth". The promise of a better life hereafter still pervades them but their joyousness and extrovert behavior suggest happiness achieved in this life in preparation for the next (199).

Hughes heard the pulsing drama of the life of the spirit, the human spirit. It was a spirit he tried to capture in poems like "Fire" and "Sunday Morning Prophecy". He heard the same pulse in the blues too. He wrote more about blues than he did about gospel music in his lifetime. He first heard the blues in Kansas City, and discovered that it was the call of his heart as it represented Black Aesthetic 
in America: "All my life I've heard the blues" ("I Remember the Blues," 152). Hughes differentiated blues clearly from the spirituals, and in a letter to Van Vechten, Hughes indicated his attitude about the blues:

The Blues always impressed me as being very sad, sadder even than spirituals because their sadness is not softened with tears but hardened with laughter, the absurd, incongruous laughter of a sadness without even a god to appeal to. In the Gulf Coast Blues one can feel the cold northern snows, the memory of the melancholy mists of the Louisiana low-lands, the shack that is home, the much oblige, the eternal unsatisfied longings. (qtd.in Rampersad 134)

Hughes's blues songs are sad songs sung to the most despondent rhythm in the orld, and display laughter under sorrow that indicates a love of life too precious to let it go. Despite the differences between spirituals and blues that Hughes enumerated in "Songs Called the Blues," he saw a greater inherent bond that transcended what he saw as the superficial discordances between the blues and spiritual and gospel music. The music, his art, black art, was not to be isolating but ultimately unifying. His black music- - tender, humorous, tragic, innocent, sexy, ecstatic, mundane, playful, lively and deadly serious- - set the stage for his emergence as an artist.

Hughes delighted in reciting his poetry to musical accompaniment, seeing the performance as an occasion for meaningful interaction that would enhance and strengthen communication. He sought to infuse much of his poetry with the urgency, the immediacy of activity and performances. He wrote in "Aunt Sue's Stories."

\section{Black slaves}

Working in the hot sun,

And black slaves

Walking in the dewy night,

And black slaves

Singing sorrow songs on the banks of a mighty river

Mingle themselves softly

In the flow of Aunt Sue's voice,

Mingle themselves softly

In the dark shadows that cross and recross

Aunt Sue's stories. (Selected Poems 6)

The performance of the poem becomes a nexus, a dialogue, something as old as the inception of theb poem but as new as the inflection of the impulse. In the stage directions to Tambourines to Glory Hughes suggested that "audience participation might be encouraged- singing, foot-patting, handclapping- - and in the program of the lyrics of some of the songs might be printed with an invitation to sing the refrains along with the chorus of Tambourine Temple" (184). It would not like likely take much to inspire participation for, as Hughes wrote in "Spirituals," "Song is a strong thing" (Selected Poems 28).

Hughes had his limitations as a commentator on the blues. His discussions of the roots of the blues in African music and work songs and field hollers were often general and unsystematic early in his career, though his later work was somewhat more comprehensive. He over generalized a bit about the types of blues that males sang as opposed to females, and he did not adequately convey the breadth of themes or 
stanzaic patterns present in the blues. His lists of outstanding blues singers most often emphasized vaudeville blues singers, certainly urban blues singers at any rate, indicating more of a preference for sophisticated productions.

The blues poems that Hughes wrote were often thematic rather than associative, and they contained noticeably few references to drugs, sex, and violence in comparison to blues songs recorded both in the field and in the studio, opting for something of a via media in reflecting the themes and images of the folk tradition. His language and images are not often as stark or startling as the best blues lyrics by performers within the oral tradition, but they make excellent use of both oral or written traditions in a way that adds materially to both, making his poetry something quite familiar, yet quite new. Not all of Hughes's blues poem employed blues stanza forms. Hughes called his poem "cross," for example, a poem whose "mood is that of the blues, although its lyric form lacks the folk repetition" ("From the Blues to an Opera Libretto"). It is not stanza form, repetition, or the number of measures in a stanza that makes the blues- - but the feeling, spirit, attitude, and approach. And these indoctrinate much of the poetry of Hughes to such an extent that the whine of a bottleneck, or the wail of a harmonica, or the trill of a piano may be regularly inferred as the subtext of his work.

Ask Your Mama, a long experimental poem, published in 1961 is illustrative of Hughes's lifelong engagement with African American music and identity, and their relationships to domestic and international structures of white supremacy, even as the poem's experimentalism eluded the appreciation of critics' contemporary and since (Rampersad 343-44). "Blues in Stereo," the fifth section of Ask Your Mama, evokes colonialism in Africa and the slaughter in King Leopold's Congo, and alludes to the ways that black music is misheard if not misappropriated by those who consider themselves the superior of people of African descent.

This essay looks at another side of the connection between Langston Hughes and the black musical tradition. The question typically posed about this relationship is, what has Hughes to say about the black musical tradition? But let us instead consider the question's inversion: what has the black musical tradition to say about Langston Hughes? I will shortly consider several jazz performances of Hughes texts, but first, a bit more contextualization.

The setting of poetry to music has a long history in the West, dating back at least to ancient Greece, and this practice has continued to be commonplace in the European concert music tradition. Thus, when one adds up all the known recordings of Langston Hughes texts with music, one finds quite a few, perhaps the majority, from composers and performers of concert music. African American composers Florence Prince, Howard Swanson, and Margaret Bonds each set several Hughes poems to their compositions, and these have been performed and recorded repeatedly over the years. Bonds, a friend of Hughes, organized and assembled a 1964 tribute, "The Poetry of Langston Hughes Set to Music on the Occasion of Mr. Hughes' Birthday," that is representative of this thrust, featuring the music of William Grant Still, Harry T. Burleigh, and other major figures of the theater and concert stage. (3)

One might think that given Hughes's fondness for writing blues verse, he might have a presence in blues or rhythm and blues music, but that is not really the case. (Neither R\&B nor blues is big on literary allusions or erudition.) In 1958, R\&B singer Big Miller recorded Did You Ever Hear The Blues, an album of Hughes blues songs taken from his theatrical works (as distinct from his numerous blues poems).In the 1990s, Washington, D. C. disc jockey and performer Nap Turner recorded readings of Hughes's simple stories with light jazz accompaniment; an album of this material was released posthumously in 2006 as Hughes Views of the Blues. Probably the most visible performance of Hughes blues material was "Goodbye Newport Blues," by the Muddy Waters Band at the 1960 Newport Jazz Festival. This was the year the festival was undone by the rioting of what producer George Wein referred to as a "large mob of inebriated kids." In response to the violence, the city council canceled the remainder of the festival, leaving the Sunday evening blues program, hosted 
by Hughes, a festival advisory board member, to be the final event. As the story goes, Hughes composed "Goodbye Newport Blues" on the back of a Western Union envelope and handed it to Waters as the band returned to the stage for an encore. Pianist Otis Spann sang the lament "it's a gloomy day in Newport / one of the worst times they ever had", which apparently was in fact the closing number of the festival (Rampersad 315).

Indeed, African American music, its beauty, cultural meanings, and creative representations of the people, was absolutely central to Langston Hughes's artistic project. His poetry and fiction return again and again to the figure of the black musician and scenes of music-making; his characters express themselves through traditional songs and songs forms, and he pioneered in adapting the twelve-bar blues form to the printed page. "Death Chant" in Shakespeare in Harlem is an example of twelve-bar blues which Hughes accomplishes through bluntness and repetition in the diction. "Bound No'th Blues" is in the exact format of the traditional folk blues. It is another moaning blues that makes noticeable use of repetition to create pace and mood, and the theme of wandering alone in the world down some interminable road is common in blues lyrics. One of Hughes's most successful gospel-influenced poems was "Fire" in which peace and mood are controlled and slowed by repetition and line placement, and the emotional force of the passage resides in the triadic refrain, which builds from one word in the first line to two in the second tom an outburst of five in the third, and then becomes a refrain of five lines, the final three elongated anguished cries, at the end.

In a nutshell, it can be said that He writes from the point of view of struggling jazz musicians, frustrated dreamers, disenfranchised students, biracial children, and so on, finding dignity in their daily struggles. Hughes's work calls attention to his characters' strength, endurance, and the purity of their souls. He praises their physical beauty as well, defying the "white" standards of beauty that dominated popular culture during the early 20th Century.

Music, particularly blues and jazz, permeates Langston Hughes's oeuvre. Many of his poems have an identifiable rhythm or beat. The lines read like the verses in a blues song and echo themes that are common in blues music, like sorrow, lost love, anger, and hopelessness. Hughes frequently alludes to music that originated during the era of slavery, using a 'call and response' pattern for auditory effect and to create a link between the past and the present. By invoking the musical traditions of slaves, Hughes connects himself to the painful history of African Americans. Hughes's poetry, like jazz and blues, has a distinct and expressive tone, often depicting tales of sorrow, alienation, and loneliness.

\section{Works Cited}

Ellison, Ralph. Invisible Man. New York: Vintage, 1989.

Hughes, Langston. "From the Blues to an Opera Libretto." New York Times. January 15, 1950.

"I Remember the Blues." In Missouri Reader. Ed. Frank Luther Motto. Columbia:

University of Missouri Press, 1964. 152-155.

. "Songs Called the Blues." Phylon 2.2 (1941): 143-145. 
Tambourines to Glory. In Five Plays by Langston Hughes. Bloomington: Indian

University Press, 1968.

Oliver, Paul, Max Harrison, and William Bolcom. The New Grove Gospel, Blues and Jazz, with Spirituals and Ragtime. London: Macmillan, 1986.

Rampersad, Arnold. The Life of Langston Hughes, Vol. I. New York: Oxford University Press, 1986. 